\title{
Lowering and Stabilizing PSA Levels in Advanced-prostate Cancer Patients With Oral Methioninase
}

\author{
QINGHONG HAN and ROBERT M. HOFFMAN
}

AntiCancer, Inc., San Diego, CA, U.S.A.

\begin{abstract}
Background/Aim: Methionine addiction is a general and fundamental hallmark of cancer due to the excess use of methionine for transmethylation reactions, termed the "Hoffman Effect". Methionine addiction has been shown to be a highlyeffective target for cancer therapy by methionine restriction with oral recombinant methioninase (o-rMETase) in preclinical studies, including patient- derived orthotopic xenograft (PDOX) mouse models of cancer. A clinical study of o-rMETase as a supplement showed a $70 \%$ reduction of PSA levels in a patient with bone-metastatic prostate cancer. Materials and Methods: In the present study, two advanced prostate-cancer patients took o-rMETase as a supplement for approximately one month. Results: One of the patients taking o-rMETase showed a $38 \%$ reduction of PSA levels and the second patient showed a $20 \%$ PSA reduction. Conclusion: o-rMETase shows promise for treating patients with advanced prostate cancer.
\end{abstract}

Methionine addiction is a general and fundamental hallmark of cancer that greatly distinguishes all tested cancer types from normal cells, with respect to their high requirement levels for methionine (1-8). The methionine addiction of cancer cells is due to excess transmethylation reactions, compared to normal cells, which leads to methionine overuse and depletion of the cellular pools of free methionine and Sadenosylmethionine $(7,8)$, which is called the "Hoffman Effect" (9-11), a possibly stronger effect than the Warburg effect for glucose (12). The elevated transmethylation in cancer is due in part to the over-methylation of histone $\mathrm{H}-3$ lysine marks $(13,14)$.

Targeting methionine addiction in cancer with recombinant methioninase (rMETase), cloned from $P$. putida

This article is freely accessible online.

Correspondence to: Robert M. Hoffman, Ph.D., AntiCancer, Inc. 7917 Ostrow St. San Diego, CA 92111, U.S.A. Tel: +1 8586542555. e-mail: all@anticancer.com

Key Words: Methioninase, oral, methionine addiction, prostate cancer, PSA, patients, response. and expressed in Escherichia coli (15), has been shown to be effective against all major cancer types in mouse models of cancer, including patient-derived orthotopic xenograft (PDOX) mouse models (16-42).

Previous preliminary safety studies on i.v. PEGylated rMETase in macaque monkeys showed that rMETase depleted plasma methionine to $<5 \mu \mathrm{mol} / \mathrm{l}$, with transient anemia being the only side effect (43). PEGylation of rMETase was necessary to prevent anaphylaxis due to repeated treatment (43). i.v. injection of rMETase also caused rapid loss of the rMETase co-factor pyrodoxal 5-phosphate (PLP) and thereby, a loss of its enzymatic activity (43).

A previous pilot Phase I clinical trial of o-rMETase was carried out to determine rMETase toxicity and the extent of methionine depletion in high-stage cancer patients. Circulating methionine levels were lowered to $0.1 \mu \mathrm{M}$ by short-term i.v. rMETase treatment, without toxicity $(44,45)$.

The discovery that rMETase could be effectively administered orally (o-rMETase) (26), solved the problem of anaphylaxis and dissociation of PLP from rMETase, since orMETase exerts its effects in the gastro-intestinal tract without entering the circulation. o-rMETase has been shown to be highly effective against recalcitrant sarcoma, pancreatic cancer, colon cancer, and melanoma in PDOX mouse models (17-20, 24-26, 32, 33, 39).

Prostate cancer is the second-leading cause of death of North American men (46). Prostate-specific antigen (PSA) is a blood biomarker of prostate cancer and its progression (46). Androgen-deprivation therapy has been combined with docetaxel to improve survival of prostate cancer patients (4649). However, survival of hormone-independent prostate cancer patients is low (47), and in need of improved therapy.

Due to the very low toxicity of o-rMETase, a pilot clinical study of o-rMETase, as a supplement, was initiated in 2020, with an advanced prostate-cancer patient with bonemetastatic disease. During a three-month period of receiving o-rMETase as a supplement, the patient had a $70 \%$ drop in his PSA levels, without any side effects (50). In the present study, we report a reduction in PSA levels in two additional advanced prostate cancer patients taking o-rMETase as a supplement, without side effects. 


\section{Materials and Methods}

rMETase production and formulation. rMETase was fermented in recombinant E. coli and purified using column chromatography, as previously described (15). Pure methioninase was dissolved in phosphate-buffered saline (PBS) at $5 \mathrm{mg} / \mathrm{ml}$ (250 units), which comprised one dose for oral administration, to be taken after breakfast and dinner.

Methionine measurement. Methionine was measured in the plasma by high performance liquid chromatography as previously described (51).

\section{Results}

Patients. Two prostate-cancer patients were treated with orMETase twice a day with a dose of 250 units each time. Patient \#1 was 55 years old, and had a $35 \mathrm{~mm}$ prostate cancer at diagnosis. The patient was initially treated with image-guided radiotherapy. This patient had a Gleason score of 4+3, with perineural invasion and extracapsular extension. Patient \#2 was 90 years old, and was diagnosed with prostate cancer, with rapidly rising PSA levels.

PSA reduction by o-rMETase. Patient \#1 had a $38.3 \%$ PSA drop within four weeks (Figure 1). Patient \#2 had a $20.1 \%$ PSA drop within four weeks which then stabilized (Figure 2).

Circulating methionine reduction by o-rMETase. Patient \#1 had a $42.7 \%$ drop in methionine levels during a 12-day period of taking o-rMETase (Figure 3).

\section{Discussion}

o-rMETase has been previously shown to cause a 70\% drop in the PSA levels of a bone-metastatic prostate-cancer patient who was treated with o-rMETase as a supplement for 3 months, with a starting PSA value of over $2000 \mathrm{ng} / \mathrm{ml} \mathrm{(50).}$

Initially, rMETase was administered intra-venously or intra-peritoneally in mouse models $(1,21,44,45)$. However, primate studies showed that repeated i.v. infusion of rMETase caused anaphylaxis, which could be prevented by PEGylation of rMETase (43). In 2018, it was found that rMETase could be effectively administered orally (o-rMETase) (26), and subsequent studies showed that o-rMETase was effective in PDOX models against all major cancer types (17-20, 24-26, $32,33,39)$. o-rMETase does not appear to enter the blood stream, thereby eliminating the risk of anaphylaxis, as well as eliminating loss of activity due to dissociation of the rMETase co-factor PLP. o-rMETase functions in the gut to degrade methionine, which subsequently lowers the blood levels of methionine, since there is no longer a source of external methionine (26).

o-rMETase is therefore much safer than injecting rMETase into the blood stream (52), and has allowed the initial

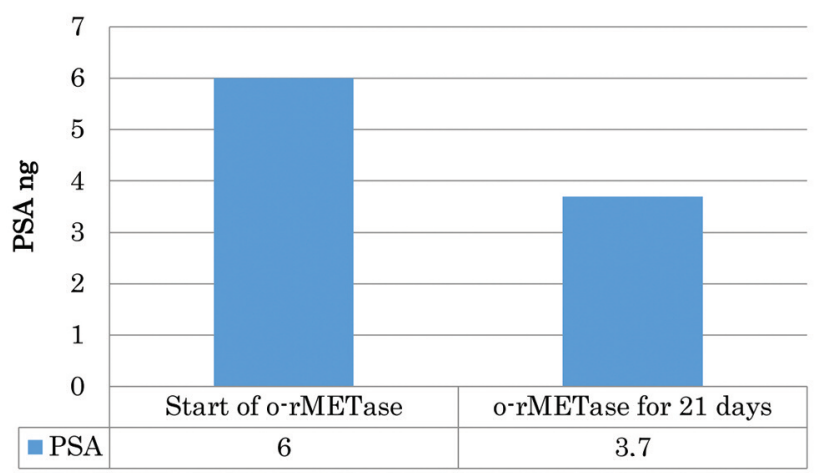

Figure 1.PSA levels in patient \#1 before and after receiving o-rMETase as a supplement for 21 days. The patient took two daily doses of 250 units of o-rMETase.

development of o-rMETase as a supplement for patients. The fact that the origin of o-rMETase was in P. putida, a soil bacterium that survives in environments with a wide range of $\mathrm{pH}$, enabled o-rMETase to evolve into an acid-resistant enzyme that can survive the low $\mathrm{pH}$ of the stomach $(1,26)$.

The two prostate-cancer patients in the present report responded to o-rMETase as observed by the reduction in PSA levels (Figures 1 and 2). Patient \#1 periodically fasted and was on a vegan diet, which may have affected his methionine and PSA levels.

The present dose of 250 units twice a day may be modified in the future in order to maximally lower the circulating methionine levels. Modifying the diet with low methionine-containing foods (53), may also be helpful along with altered dosing and scheduling of o-rMETase, to lower methionine and PSA levels even further. After optimization of the dose, schedule and diet, cancer patients can be treated with combinations of o-rMETase and chemotherapy, as methionine restriction and chemotherapy were found to be synergistic $(6,36)$. Most promising is combination chemotherapy along with o-rMETase for blockade of the methionine-methylation axis (54-56).

\section{Conflicts of Interest}

The Authors report no conflicts of interest in relation to this study.

\section{Authors' Contributions}

Qinghong Han produced the recombinant methioninase and analyzed the data. Robert M. Hoffman wrote the paper.

\section{Acknowledgements}

This paper is dedicated to the memory of John Mays, AR Moossa, MD, Sun Lee, MD, Professor Li Jiaxi and Masaki Kitajima, MD. 


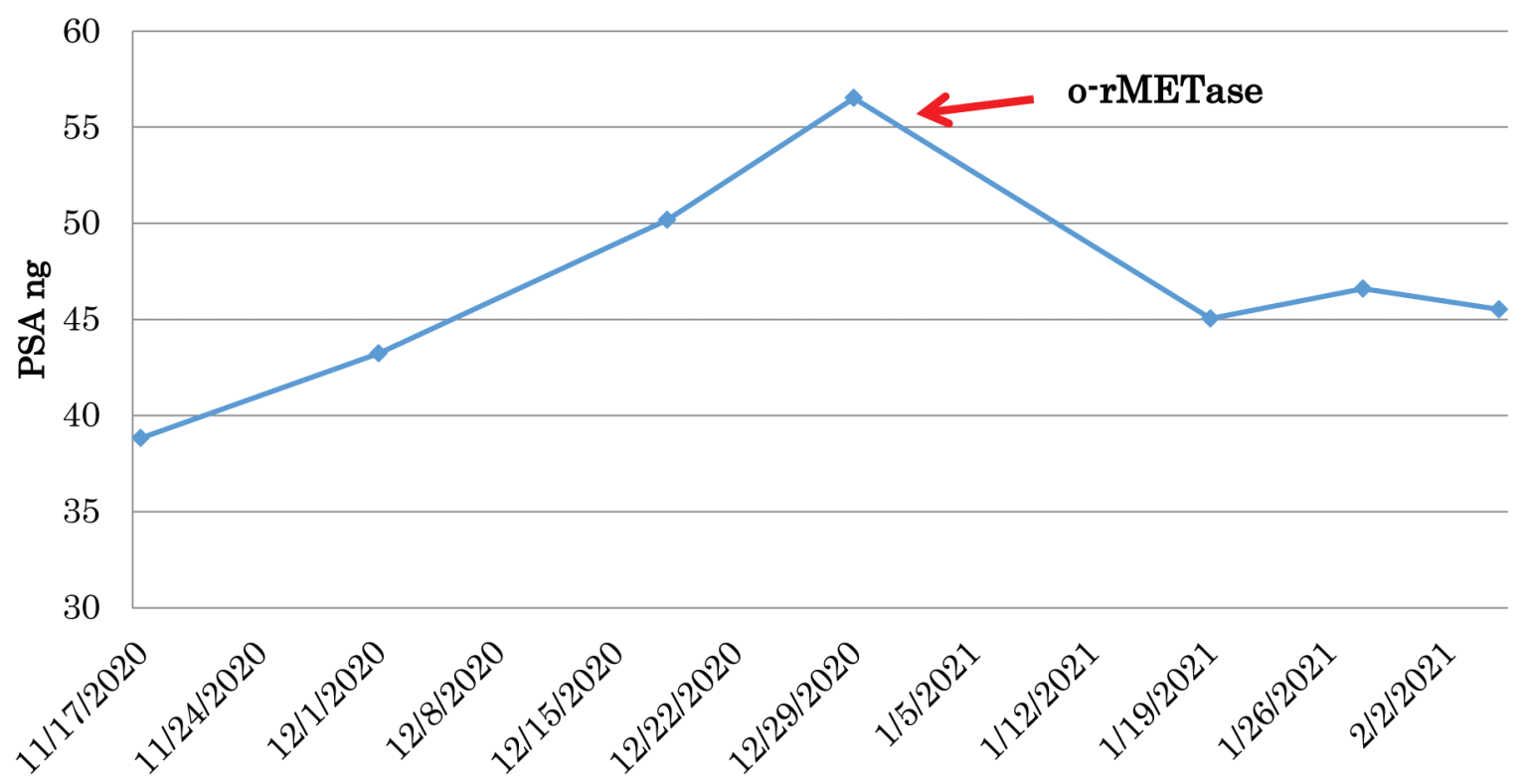

Figure 2. PSA levels in patient \#2 before and during his treatment with o-rMETase, twice daily, 250 units/dose. Red arrow indicates the start of o-rMETase treatment.

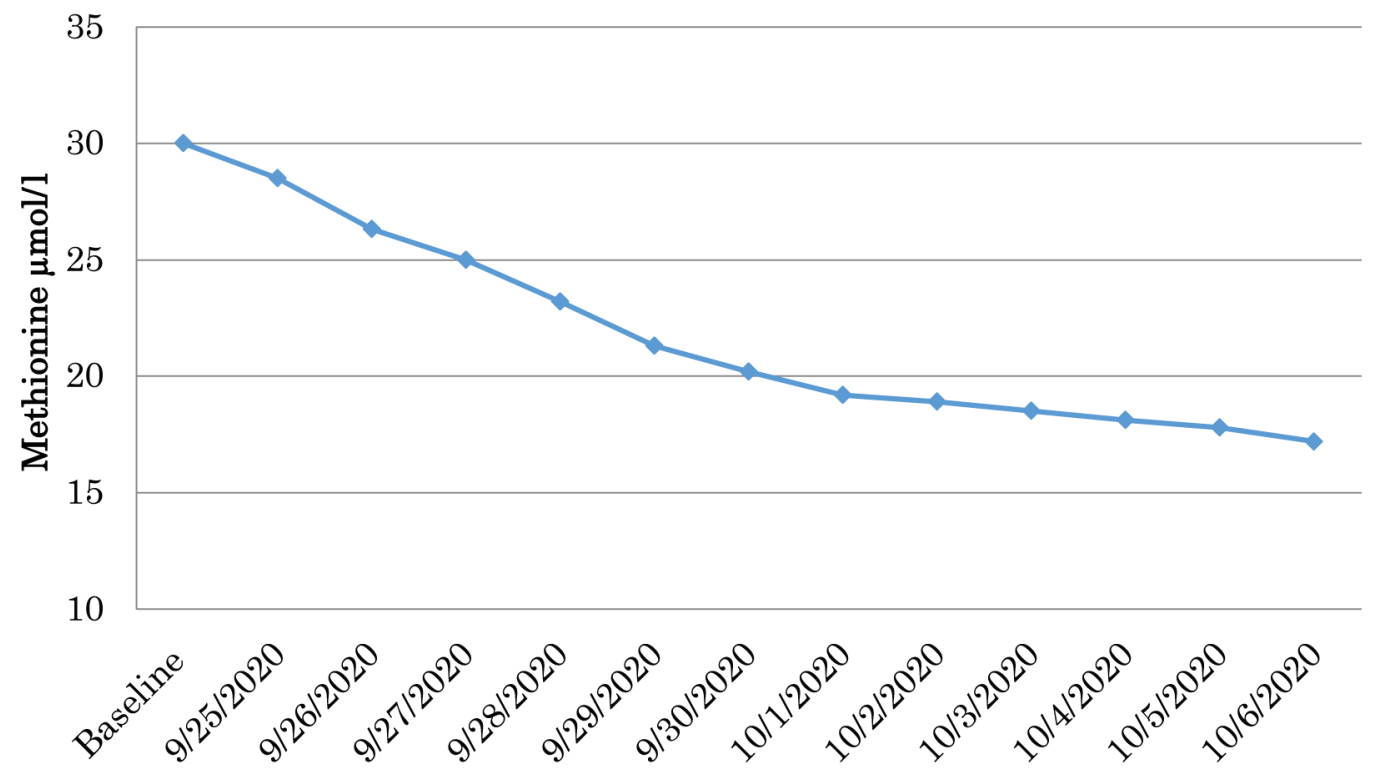

Figure 3. Daily methionine levels in the plasma of patient \#1 during treatment with o-rMETase, twice daily, 250 units/dose.

\section{References}

1 Hoffman RM: Development of recombinant methioninase to target the general cancer-specific metabolic defect of methionine dependence: A 40-year odyssey. Expert Opin Biol Ther 15(1): 2131, 2015. PMID: 25439528. DOI: 10.1517/14712598.2015.963050
2 Hoffman RM and Erbe RW: High in vivo rates of methionine biosynthesis in transformed human and malignant rat cells auxotrophic for methionine. Proc Natl Acad Sci USA 73(5): 1523-1527, 1976. PMID: 179090. DOI: 10.1073/pnas.73.5.1523

3 Hoffman RM and Jacobsen SJ: Reversible growth arrest in simian virus 40 -transformed human fibroblasts. Proc Natl Acad 
Sci USA 77(12): 7306-7310, 1980. PMID: 6261250. DOI: 10.1073/pnas.77.12.7306

4 Guo H, Lishko VK, Herrera H, Groce A, Kubota T and Hoffman RM: Therapeutic tumor-specific cell cycle block induced by methionine starvation in vivo. Cancer Res 53(23): 5676-5679, 1993. PMID: 8242623.

5 Yano S, Li S, Han Q, Tan Y, Bouvet M, Fujiwara T and Hoffman RM: Selective methioninase-induced trap of cancer cells in S/G2 phase visualized by FUCCI imaging confers chemosensitivity. Oncotarget 5(18): 8729-8736, 2014. PMID: 25238266. DOI: 10.18632/oncotarget.2369

6 Stern PH and Hoffman RM: Enhanced in vitro selective toxicity of chemotherapeutic agents for human cancer cells based on a metabolic defect. J Natl Cancer Inst 76(4): 629-639, 1986. PMID: 3457200. DOI: 10.1093/jnci/76.4.629

7 Stern PH and Hoffman RM: Elevated overall rates of transmethylation in cell lines from diverse human tumors. In Vitro 20(8): 663-670, 1984. PMID: 6500606. DOI: 10.1007/ BF02619617

8 Coalson DW, Mecham JO, Stern PH and Hoffman RM: Reduced availability of endogenously synthesized methionine for Sadenosylmethionine formation in methionine-dependent cancer cells. Proc Natl Acad Sci USA 79(14): 4248-4251, 1982. PMID: 6289297. DOI: $10.1073 /$ pnas.79.14.4248

9 Kaiser P: Methionine dependence of cancer. Biomolecules 10(4): 568, 2020. PMID: 32276408. DOI: 10.3390/biom 10040568

10 Lauinger L and Kaiser P: Sensing and signaling of methionine metabolism. Metabolites 11(2): 83, 2021. PMID: 33572567. DOI: $10.3390 /$ metabo11020083

11 Borrego SL, Fahrmann J, Hou J, Lin DW, Tromberg BJ, Fiehn $\mathrm{O}$ and Kaiser P: Lipid remodeling in response to methionine stress in MDA-MBA-468 triple-negative breast cancer cells. J Lipid Res Feb 26:100056, 2021. Epub ahead of print. PMID: 33647277. DOI: 10.1016/j.jlr.2021.100056

12 Pirotte B, Goldman S, Massager N, David P, Wikler D, Vandesteene A, Salmon I, Brotchi J and Levivier M: Comparison of $18 \mathrm{~F}-\mathrm{FDG}$ and $11 \mathrm{C}$-methionine for PET-guided stereotactic brain biopsy of gliomas. J Nucl Med 45(8): 1293-1298, 2004. PMID: 15299051.

13 Yamamoto J,Inubushi S, Han Q, TashiroY, Sun Y, Sugisawa N, Hamada K, Nishino H, Aoki Y,Miyake K, Matsuyama R, Bouvet M, Endo I and Hoffman RM: Cancer-specific overmethylation of histone $\mathrm{H} 3$ lysines is necessary for methionine addiction and malignancy. BioRxiv, 2020. DOI:10.1101/2020.12.04.412437

14 Yamamoto J, Han Q, Inubushi S, Sugisawa N, Hamada K, Nishino H, Miyake K, Kumamoto T, Matsuyama R, Bouvet M, Endo I and Hoffman RM: Histone methylation status of $\mathrm{H} 3 \mathrm{~K} 4 \mathrm{me} 3$ and $\mathrm{H} 3 \mathrm{~K} 9 \mathrm{me} 3$ under methionine restriction is unstable in methionine-addicted cancer cells, but stable in normal cells. Biochem Biophys Res Commun 533(4): 10341038, 2020. PMID: 33019978. DOI: 10.1016/j.bbrc.2020.09.108

15 Tan Y, Xu M, Tan X, Tan X, Wang X, Saikawa Y, Nagahama T, Sun X, Lenz M and Hoffman RM: Overexpression and largescale production of recombinant L-methionine-alpha-deaminogamma-mercaptomethane-lyase for novel anticancer therapy. Protein Expr Purif 9(2): 233-245, 1997. PMID: 9056489. DOI: 10.1006/prep.1996.0700

16 Igarashi K, Kawaguchi K, Kiyuna T, Miyake K, Murakami T, Yamamoto N, Hayashi K, Kimura H, Miwa S, Tsuchiya H and Hoffman RM: Effective metabolic targeting of human osteosarcoma cells in vitro and in orthotopic nude-mouse models with recombinant methioninase. Anticancer Res 37(9): 48074812, 2017. PMID: 28870899. DOI: 10.21873/anticanres.11887

17 Higuchi T, Han Q, Miyake K, Oshiro H, Sugisawa N, Tan Y, Yamamoto N, Hayashi K, Kimura H, Miwa S, Igarashi K, Bouvet M, Singh SR, Tsuchiya $\mathrm{H}$ and Hoffman RM: Combination of oral recombinant methioninase and decitabine arrests a chemotherapy-resistant undifferentiated soft-tissue sarcoma patient-derived orthotopic xenograft mouse model. Biochem Biophys Res Commun 523(1): 135-139, 2020. PMID: 31839218. DOI: 10.1016/j.bbrc.2019.12.024

18 Higuchi T, Sugisawa N, Yamamoto J, Oshiro H, Han Q, Yamamoto N, Hayashi K, Kimura H, Miwa S, Igarashi K, Tan Y, Kuchipudi S, Bouvet M, Singh SR, Tsuchiya H and Hoffman RM: The combination of oral-recombinant methioninase and azacitidine arrests a chemotherapy-resistant osteosarcoma patientderived orthotopic xenograft mouse model. Cancer Chemother Pharmacol 85(2): 285-291, 2020. PMID: 31705268. DOI: 10.1007/s00280-019-03986-0

19 Oshiro H, Tome Y, Kiyuna T, Yoon SN, Lwin TM, Han Q, Tan Y, Miyake K, Higuchi T, Sugisawa N, Katsuya Y, Park JH, Zang Z, Razmjooei S, Bouvet M, Clary B, Singh SR, Kanaya F, Nishida K and Hoffman RM: Oral recombinant methioninase overcomes colorectal-cancer liver metastasis resistance to the combination of 5 -fluorouracil and oxaliplatinum in a patient-derived orthotopic xenograft mouse model. Anticancer Res 39(9): 4667-4671, 2019. PMID: 31519565. DOI: 10.21873/anticanres.13648

20 Higuchi T, Oshiro H, Miyake K, Sugisawa N, Han Q, Tan Y, Park J, Zhang Z, Razmjooei S, Yamamoto N, Hayashi K, Kimura H, Miwa S, Igarashi K, Bouvet M, Chawla SP, Singh SR, Tsuchiya $\mathrm{H}$ and Hoffman RM: Oral recombinant methioninase, combined with oral caffeine and injected cisplatinum, overcome cisplatinum-resistance and regresses patient-derived orthotopic xenograft model of osteosarcoma. Anticancer Res 39(9): 4653-4657, 2019. PMID: 31519563. DOI: 10.21873/anticanres.13646

21 Kawaguchi K, Han Q, Li S, Tan Y, Igarashi K, Murakami T, Unno $M$ and Hoffman RM: Efficacy of recombinant methioninase (rMETase) on recalcitrant cancer patient-derived orthotopic xenograft (PDOX): A review. Cells 8(5): 410, 2019. PMID: 31052611. DOI: 10.3390/cells 8050410

22 Miyake K, Kiyuna T, Li S, Han Q, Tan Y, Zhao M, Oshiro H, Kawaguchi K, Higuchi T, Zhang Z, Razmjooei S, Barangi M, Wangsiricharoen S, Murakami T, Singh AS, Li Y, Nelson SD, Eilber FC, Bouvet M, Hiroshima Y, Chishima T, Matsuyama R, Singh SR, Endo I and Hoffman RM: Combining tumor-selective bacterial therapy with Salmonella typhimurium A1-R and cancer metabolism targeting with oral recombinant methioninase regressed an Ewing's sarcoma in a patient-derived orthotopic xenograft model. Chemotherapy 63(5): 278-283, 2018. PMID: 30673664. DOI: $10.1159 / 000495574$

23 Igarashi K, Kawaguchi K, Kiyuna T, Miyake K, Miyaki M, Yamamoto N, Hayashi K, Kimura H, Miwa S, Higuchi T, Singh AS, Chmielowski B, Nelson SD, Russell TA, Eckardt MA, Dry SM, Li Y, Singh SR, Chawla SP, Eilber FC, Tsuchiya H and Hoffman RM: Metabolic targeting with recombinant methioninase combined with palbociclib regresses a doxorubicin-resistant dedifferentiated liposarcoma. Biochem Biophys Res Commun 506(4): 912-917, 2018. PMID: 30392912. DOI: 10.1016/ j.bbrc.2018.10.119 
24 Higuchi T, Kawaguchi K, Miyake K, Han Q, Tan Y, Oshiro H, Sugisawa N, Zhang Z, Razmjooei S, Yamamoto N, Hayashi K, Kimura H, Miwa S, Igarashi K, Chawla SP, Singh AS, Eilber FC, Singh SR, Tsuchiya H and Hoffman RM: Oral recombinant methioninase combined with caffeine and doxorubicin induced regression of a doxorubicin-resistant synovial sarcoma in a PDOX mouse model. Anticancer Res 38(10): 5639-5644, 2018. PMID: 30275182. DOI: 10.21873/anticanres.12899

25 Kawaguchi K, Higuchi T, Li S, Han Q, Tan Y, Igarashi K, Zhao M, Miyake K, Kiyuna T, Miyake M, Ohshiro H, Sugisawa N, Zhang Z, Razmjooei S, Wangsiricharoen S, Chmielowski B, Nelson SD, Russell TA, Dry SM, Li Y, Eckardt MA, Singh AS, Singh SR, Eilber FC, Unno M and Hoffman RM: Combination therapy of tumor-targeting Salmonella typhimurium A1-R and oral recombinant methioninase regresses a BRAF-V600E-negative melanoma. Biochem Biophys Res Commun 503(4): 3086-3092, 2018. PMID: 30166061. DOI: 10.1016/j.bbrc.2018.08.097

26 Kawaguchi K, Miyake K, Han Q, Li S, Tan Y, Igarashi K, Kiyuna T, Miyake M, Higuchi T, Oshiro H, Zhang Z, Razmjooei S, Wangsiricharoen S, Bouvet M, Singh SR, Unno M and Hoffman RM: Oral recombinant methioninase (o-rMETase) is superior to injectable rMETase and overcomes acquired gemcitabine resistance in pancreatic cancer. Cancer Lett 432: 251-259, 2018. PMID: 29928962. DOI: 10.1016/j.canlet.2018.06.016

27 Kawaguchi K, Miyake K, Han Q, Li S, Tan Y, Igarashi K, Lwin TM, Higuchi T, Kiyuna T, Miyake M, Oshiro H, Bouvet M, Unno M and Hoffman RM: Targeting altered cancer methionine metabolism with recombinant methioninase (rMETase) overcomes partial gemcitabine-resistance and regresses a patientderived orthotopic xenograft (PDOX) nude mouse model of pancreatic cancer. Cell Cycle 17(7): 868-873, 2018. PMID: 29623758. DOI: 10.1080/15384101.2018.1445907

28 Kawaguchi K, Han Q, Li S, Tan Y, Igarashi K, Miyake K, Kiyuna T, Miyake M, Chemielwski B, Nelson SD, Russell TA, Dry SM, Li Y, Singh AS, Eckardt MA, Unno M, Eilber FC and Hoffman RM: Intra-tumor L-methionine level highly correlates with tumor size in both pancreatic cancer and melanoma patientderived orthotopic xenograft (PDOX) nude-mouse models. Oncotarget 9(13): 11119-11125, 2018. PMID: 29541401. DOI: 10.18632 /oncotarget. 24264

29 Kawaguchi K, Igarashi K, Li S, Han Q, Tan Y, Kiyuna T, Miyake K, Murakami T, Chmielowski B, Nelson SD, Russell TA, Dry SM, Li Y, Unno M, Eilber FC and Hoffman RM: Combination treatment with recombinant methioninase enables temozolomide to arrest a BRAF V600E melanoma in a patient-derived orthotopic xenograft (PDOX) mouse model. Oncotarget 8(49): 85516-85525, 2017. PMID: 29156737. DOI: $10.18632 /$ oncotarget.20231

30 Igarashi K, Kawaguchi K, Kiyuna T, Miyake K, Miyake M, Li S, Han Q, Tan Y, Zhao M, Li Y, Nelson SD, Dry SM, Singh AS, Elliott IA, Russell TA, Eckardt MA, Yamamoto N, Hayashi K, Kimura H, Miwa S, Tsuchiya H, Eilber FC and Hoffman RM: Tumor-targeting Salmonella typhimurium A1-R combined with recombinant methioninase and cisplatinum eradicates an osteosarcoma cisplatinum-resistant lung metastasis in a patient-derived orthotopic xenograft (PDOX) mouse model: Decoy, trap and kill chemotherapy moves toward the clinic. Cell Cycle 17(6): 801-809, 2018. PMID: 29374999. DOI: 10.1080/15384101.2018.1431596

31 Igarashi K, Kawaguchi K, Li S, Han Q, Tan Y, Murakami T, Kiyuna T, Miyake K, Miyake M, Singh AS, Eckardt MA, Nelson SD, Russell TA, Dry SM, Li Y, Yamamoto N, Hayashi K,
Kimura H, Miwa S, Tsuchiya H, Singh SR, Eilber FC and Hoffman RM: Recombinant methioninase in combination with doxorubicin (DOX) overcomes first-line DOX resistance in a patient-derived orthotopic xenograft nude-mouse model of undifferentiated spindle-cell sarcoma. Cancer Lett 417: 168-173, 2018. PMID: 29306021. DOI: 10.1016/j.canlet.2017.12.028

32 Kawaguchi K, Han Q, Li S, Tan Y, Igarashi K, Kiyuna T, Miyake K, Miyake M, Chmielowski B, Nelson SD, Russell TA, Dry SM, Li Y, Singh AS, Eckardt MA, Unno M, Eilber FC and Hoffman RM: Targeting methionine with oral recombinant methioninase (orMETase) arrests a patient-derived orthotopic xenograft (PDOX) model of BRAF-V600E mutant melanoma: implications for chronic clinical cancer therapy and prevention. Cell Cycle 17(3): 356-361, 2018. PMID: 29187018. DOI: 10.1080/15384101.2017.1405195

33 Park JH, Han Q, Zhao M, Tan Y, Higuchi T, Yoon SN, Sugisawa N, Yamamoto J, Bouvet M, Clary B, Singh SR and Hoffman RM: Oral recombinant methioninase combined with oxaliplatinum and 5-fluorouracil regressed a colon cancer growing on the peritoneal surface in a patient-derived orthotopic xenograft mouse model. Tissue Cell 61: 109-114, 2019. PMID: 31759402. DOI: 10.1016/j.tice.2019.09.006

34 Igarashi K, Li S, Han Q, Tan Y, Kawaguchi K, Murakami T, Kiyuna T, Miyake K, Li Y, Nelson SD, Dry SM, Singh AS, Elliott IA, Russell TA, Eckardt MA, Yamamoto N, Hayashi K, Kimura H, Miwa S, Tsuchiya H, Eilber FC and Hoffman RM: Growth of doxorubicin-resistant undifferentiated spindle-cell sarcoma PDOX is arrested by metabolic targeting with recombinant methioninase. J Cell Biochem 119(4): 3537-3544, 2018. PMID: 29143983. DOI: 10.1002/jcb.26527

35 Murakami T, Li S, Han Q, Tan Y, Kiyuna T, Igarashi K, Kawaguchi K, Hwang HK, Miyake K, Singh AS, Nelson SD, Dry SM, Li Y, Hiroshima Y, Lwin TM, DeLong JC, Chishima T, Tanaka K, Bouvet M, Endo I, Eilber FC and Hoffman RM: Recombinant methioninase effectively targets a Ewing's sarcoma in a patient-derived orthotopic xenograft (PDOX) nude-mouse model. Oncotarget 8(22): 35630-35638, 2017. PMID: 28404944. DOI: $10.18632 /$ oncotarget.15823

36 Yano S, Takehara K, Zhao M, Tan Y, Han Q, Li S, Bouvet M, Fujiwara T and Hoffman RM: Tumor-specific cell-cycle decoy by Salmonella typhimurium A1-R combined with tumorselective cell-cycle trap by methioninase overcome tumor intrinsic chemoresistance as visualized by FUCCI imaging. Cell Cycle 15(13): 1715-1723, 2016. PMID: 27152859. DOI: 10.1080/15384101.2016.1181240

37 Igarashi K, Kawaguchi K, Li S, Han Q, Tan Y, Gainor E, Kiyuna T, Miyake K, Miyake M, Higuchi T, Oshiro H, Singh AS, Eckardt MA, Nelson SD, Russell TA, Dry SM, Li Y, Yamamoto N, Hayashi K, Kimura H, Miwa S, Tsuchiya H, Eilber FC and Hoffman RM: Recombinant methioninase combined with doxorubicin (DOX) regresses a DOX-resistant synovial sarcoma in a patient-derived orthotopic xenograft (PDOX) mouse model. Oncotarget 9(27): 19263-19272, 2018. PMID: 29721200. DOI: 10.18632/oncotarget.24996

38 Kawaguchi K, Igarashi K, Li S, Han Q, Tan Y, Miyake K, Kiyuna T, Miyake M, Murakami T, Chmielowski B, Nelson SD, Russell TA, Dry SM, Li Y, Unno M, Eilber FC and Hoffman RM: Recombinant methioninase (rMETase) is an effective therapeutic for BRAFV600E-negative as well as -positive melanoma in patient- derived orthotopic xenograft (PDOX) mouse models. Oncotarget 9(1): 915923, 2017. PMID: 29416666. DOI: 10.18632/oncotarget.23185 
39 Park JH, Zhao M, Han Q, Sun Y, Higuchi T, Sugisawa N, Yamamoto J, Singh SR, Clary B, Bouvet M and Hoffman RM: Efficacy of oral recombinant methioninase combined with oxaliplatinum and 5-fluorouracil on primary colon cancer in a patient-derived orthotopic xenograft mouse model. Biochem Biophys Res Commun 518(2): 306-310, 2019. PMID: 31421825. DOI: 10.1016/j.bbrc.2019.08.051

40 Yoshioka T, Wada T, Uchida N, Maki H, Yoshida H, Ide N, Kasai H, Hojo K, Shono K, Maekawa R, Yagi S, Hoffman RM and Sugita K: Anticancer efficacy in vivo and in vitro, synergy with 5-fluorouracil, and safety of recombinant methioninase. Cancer Res 58(12): 2583-2587, 1998. PMID: 9635582.

41 Kokkinakis DM, Hoffman RM, Frenkel EP, Wick JB, Han Q, Xu M, Tan Y and Schold SC: Synergy between methionine stress and chemotherapy in the treatment of brain tumor xenografts in athymic mice. Cancer Res 61(10): 4017-4023, 2001. PMID: 11358820

42 Tan Y, Sun X, Xu M, Tan X, Sasson A, Rashidi B, Han Q, Tan $X$, Wang X, An Z, Sun FX and Hoffman RM: Efficacy of recombinant methioninase in combination with cisplatin on human colon tumors in nude mice. Clin Cancer Res 5(8): $2157-$ 2163, 1999. PMID: 10473100.

43 Yang Z, Wang J, Lu Q, Xu J, Kobayashi Y, Takakura T, Takimoto A, Yoshioka T, Lian C, Chen C, Zhang D, Zhang Y, Li S, Sun X, Tan Y, Yagi S, Frenkel EP and Hoffman RM: PEGylation confers greatly extended half-life and attenuated immunogenicity to recombinant methioninase in primates. Cancer Res 64(18): 6673-6678, 2004. PMID: 15374983. DOI: 10.1158/0008-5472.CAN-04-1822

44 Tan Y, Zavala J Sr, Han Q, Xu M, Sun X, Tan X, Tan X, Magana $\mathrm{R}$, Geller $\mathrm{J}$ and Hoffman RM: Recombinant methioninase infusion reduces the biochemical endpoint of serum methionine with minimal toxicity in high-stage cancer patients. Anticancer Res 17(5B): 3857-3860, 1997. PMID: 9427792.

45 Tan Y, Zavala J Sr, Xu M, Zavala J Jr and Hoffman RM: Serum methionine depletion without side effects by methioninase in metastatic breast cancer patients. Anticancer Res 16(6C): 39373942, 1996. PMID: 9042316.

46 Sartor O and de Bono JS: Metastatic Prostate Cancer. N Engl J Med 378(7): 645-657, 2018. PMID: 29412780. DOI: 10.1056/ NEJMra1701695

47 Siegel RL, Miller KD and Jemal A: Cancer statistics, 2020. CA Cancer J Clin 70(1): 7-30, 2020. PMID: 31912902. DOI: $10.3322 /$ caac. 21590

48 Sweeney CJ, Chen YH, Carducci M, Liu G, Jarrard DF, Eisenberger M, Wong YN, Hahn N, Kohli M, Cooney MM, Dreicer R, Vogelzang NJ, Picus J, Shevrin D, Hussain M, Garcia JA and DiPaola RS: Chemohormonal therapy in metastatic hormone-sensitive prostate cancer. N Engl J Med 373(8): 737746, 2015. PMID: 26244877. DOI: 10.1056/NEJMoa1503747

49 James ND, Sydes MR, Clarke NW, Mason MD, Dearnaley DP, Spears MR, Ritchie AW, Parker CC, Russell JM, Attard G, de Bono J, Cross W, Jones RJ, Thalmann G, Amos C, Matheson D, Millman R, Alzouebi M, Beesley S, Birtle AJ, Brock S, Cathomas R, Chakraborti P, Chowdhury S, Cook A, Elliott T, Gale J, Gibbs S, Graham JD, Hetherington J, Hughes R, Laing R, McKinna F, McLaren DB, O'Sullivan JM, Parikh O, Peedell C, Protheroe A, Robinson AJ, Srihari N, Srinivasan R, Staffurth J, Sundar S, Tolan S, Tsang D, Wagstaff J, Parmar MK and STAMPEDE investigators: Addition of docetaxel, zoledronic acid, or both to first-line long-term hormone therapy in prostate cancer (STAMPEDE): Survival results from an adaptive, multiarm, multistage, platform randomised controlled trial. Lancet 387(10024): 1163-1177, 2016. PMID: 26719232. DOI: 10.1016/S0140-6736(15)01037-5

50 Han Q, Tan Y and Hoffman RM: Oral dosing of recombinant methioninase is associated with a 70\% drop in PSA in a patient with bone-metastatic prostate cancer and $50 \%$ reduction in circulating methionine in a high-stage ovarian cancer patient. Anticancer Res 40(5): 2813-2819, 2020. PMID: 32366428. DOI: 10.21873/anticanres.14254

51 Sun X, Tan Y, Yang Z, Li S and Hoffman RM: A rapid HPLC method for the measurement of ultra-low plasma methionine concentrations applicable to methionine depletion therapy. Anticancer Res 25(1A): 59-62, 2005. PMID: 15816519.

$52 \mathrm{Lu}$ WC, Saha A, Yan W, Garrison K, Lamb C, Pandey R, Irani S, Lodi A, Lu X, Tiziani S, Zhang YJ, Georgiou G, DiGiovanni J and Stone E: Enzyme-mediated depletion of serum 1-Met abrogates prostate cancer growth via multiple mechanisms without evidence of systemic toxicity. Proc Natl Acad Sci USA 117(23): 1300013011, 2020. PMID: 32434918. DOI: 10.1073/pnas.1917362117

53 Gao X, Sanderson SM, Dai Z, Reid MA, Cooper DE, Lu M, Richie JP Jr, Ciccarella A, Calcagnotto A, Mikhael PG, Mentch SJ, Liu J, Ables G, Kirsch DG, Hsu DS, Nichenametla SN and Locasale JW: Dietary methionine influences therapy in mouse cancer models and alters human metabolism. Nature 572(7769): 397-401, 2019. PMID: 31367041. DOI: 10.1038/s41586-0191437-3

54 Sugisawa N, Yamamoto J, Han Q, Tan Y, Tashiro Y, Nishino H, Inubushi S, Hamada K, Kawaguchi K, Unno M, Bouvet M and Hoffman RM: Triple-methyl blockade with recombinant methioninase, cycloleucine, and azacitidine arrests a pancreatic cancer patient-derived orthotopic xenograft model. Pancreas 50(1): 93-98, 2021. PMID: 33370029. DOI: 10.1097/MPA.0000000000001709

55 Higuchi T, Han Q, Sugisawa N, Yamamoto J, Yamamoto N, Hayashi K, Kimura H, Miwa S, Igarashi K, Bouvet M, Singh SR, Tsuchiya $\mathrm{H}$ and Hoffman RM: Combination methionine-methylation-axis blockade: A novel approach to target the methionine addiction of cancer. Cancer Genomics Proteomics 18(2):113-120, 2021. PMID: 33608308. DOI: $10.21873 /$ cgp.20246

56 Kalev P, Hyer ML, Gross S, Konteatis Z, Chen CC, Fletcher M, Lein M, Aguado-Fraile E, Frank V, Barnett A, Mandley E, Goldford J, Chen Y, Sellers K, Hayes S, Lizotte K, Quang P, Tuncay Y, Clasquin M, Peters R, Weier J, Simone E, Murtie J, Liu W, Nagaraja R, Dang L, Sui Z, Biller SA, Travins J, Marks KM and Marjon K: MAT2A inhibition blocks the growth of MTAP-deleted cancer cells by reducing PRMT5-dependent mRNA splicing and inducing DNA damage. Cancer Cell 39: 209224, 2021. PMID: 33450196. DOI: 10.1016/j.ccell.2020.12.010

Received February 22, 2021

Revised March 8, 2021

Accepted March 11, 2021 